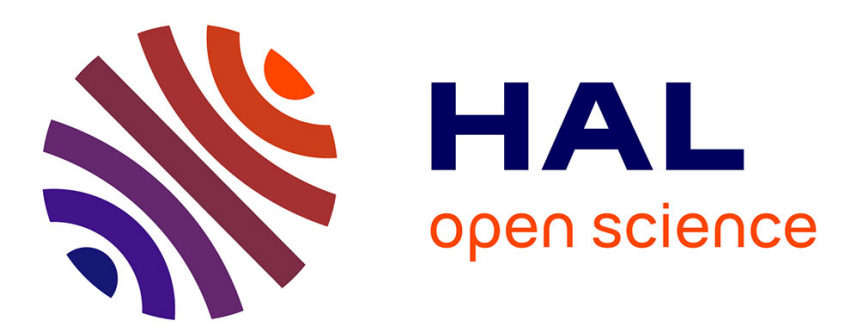

\title{
Russian Collective Gardens: A Story of Institution and Remembrance
}

\author{
Frédérick Lemarchand
}

\section{To cite this version:}

Frédérick Lemarchand. Russian Collective Gardens: A Story of Institution and Remembrance. The urban garden city: shaping the city with gardens through history, pp.79-97, 2018, Cities and nature, 978-3-319-72732-5. 10.1007/978-3-319-72733-2_5 . hal-01928677

\section{HAL Id: hal-01928677 https://hal.science/hal-01928677}

Submitted on 20 Nov 2018

HAL is a multi-disciplinary open access archive for the deposit and dissemination of scientific research documents, whether they are published or not. The documents may come from teaching and research institutions in France or abroad, or from public or private research centers.
L'archive ouverte pluridisciplinaire HAL, est destinée au dépôt et à la diffusion de documents scientifiques de niveau recherche, publiés ou non, émanant des établissements d'enseignement et de recherche français ou étrangers, des laboratoires publics ou privés. 


\section{Metadata of the chapter that will be visualized in SpringerLink}

\begin{tabular}{|c|c|c|}
\hline Book Title & \multicolumn{2}{|c|}{ The Urban Garden City } \\
\hline \multicolumn{3}{|l|}{ Series Title } \\
\hline Chapter Title & \multicolumn{2}{|c|}{ Russian Collective Gardens: A Story of Institution and Remembrance } \\
\hline Copyright Year & \multicolumn{2}{|c|}{2018} \\
\hline Copyright HolderName & \multicolumn{2}{|c|}{ Springer International Publishing AG } \\
\hline \multirow[t]{9}{*}{ Corresponding Author } & Family Name & Frédérick \\
\hline & Particle & \\
\hline & Given Name & Lemarchand \\
\hline & Prefix & \\
\hline & Suffix & \\
\hline & Division & \\
\hline & Organization & MRSH-b Pôle risque, Université de Caen \\
\hline & Address & Esplanade de la Paix, 14032, Caen Cedex, France \\
\hline & Email & frederick.lemarchand@unicaen.fr \\
\hline Abstract & \multicolumn{2}{|c|}{$\begin{array}{l}\text { Starting from a fieldwork carried out in the Republic of Tatarstan (Russia) on industrial pollution and the } \\
\text { necessity to support gardeners in changing their practices, the present research opens a socio- } \\
\text { anthropological perspective on the (sub)urban garden. The datcha is first and foremost a Soviet institution } \\
\text { that has now spread to all Russian cities to become a social, cultural, and intergenerational phenomenon. }\end{array}$} \\
\hline
\end{tabular}




\title{
Chapter 5 \\ Russian Collective Gardens: A Story of Institution and Remembrance
}

\section{Lemarchand Frédérick}

«In His life, a man has to build a house, plant a tree, father a son» Russian Proverb.

\begin{abstract}
Starting from a fieldwork carried out in the Republic of Tatarstan (Russia) on industrial pollution and the necessity to support gardeners in changing their practices, the present research opens a socio-anthropological perspective on the (sub) urban garden. The datcha is first and foremost a Soviet institution that has now spread to all Russian cities to become a social, cultural, and intergenerational phenomenon.
\end{abstract}

The collective garden, as a part of the Soviet roots of nowadays Russia, turns out to be a good vehicle of social structures exploration as well as a great tool to analyze the development of the relationship between men and nature, as the works of Hervouet (2009) or Gessat-Anstett (2001) have shown. This is why we consider it a social fact, in other words a collective, institutional, and imaginary production. This socio-anthropological approach, characterized by its double perspective ranging from the microscopic to the macroscopic scales, and referring to the study of both its symbolic and local aspects (depictions, attitudes, beliefs, practices) and the social and historical movements and structures surrounding those particular realities, appeared to be particularly relevant to grasp the intricacies of a subject located at the crossroads of culture, nature, and technique. The target program had to balance the reality of environmental and health issues by mobilizing best available scientific knowledge with another reality, namely the symbolic and socioeconomic reality, that of the complex, aesthetic, memory-based relations that the people of Russia have with these gardens. In the face of the projects to adapt to the environmental and health risks, the dialogical perspective, based on the idea of an eventual parallel between affinity scientific knowledge and social knowledge and on the assumption of their equal validity, seemed to be the most relevant one (Figs. 5.1 and 5.2).

L. Frédérick $(\bowtie)$

MRSH-b Pôle risque, Université de Caen, Esplanade de la Paix,

14032 Caen Cedex, France

e-mail: frederick.lemarchand@unicaen.fr

S. Glatron and L. Granchamp (eds.), The Urban Garden City, Cities and Nature,

https://doi.org/10.1007/978-3-319-72733-2_5 


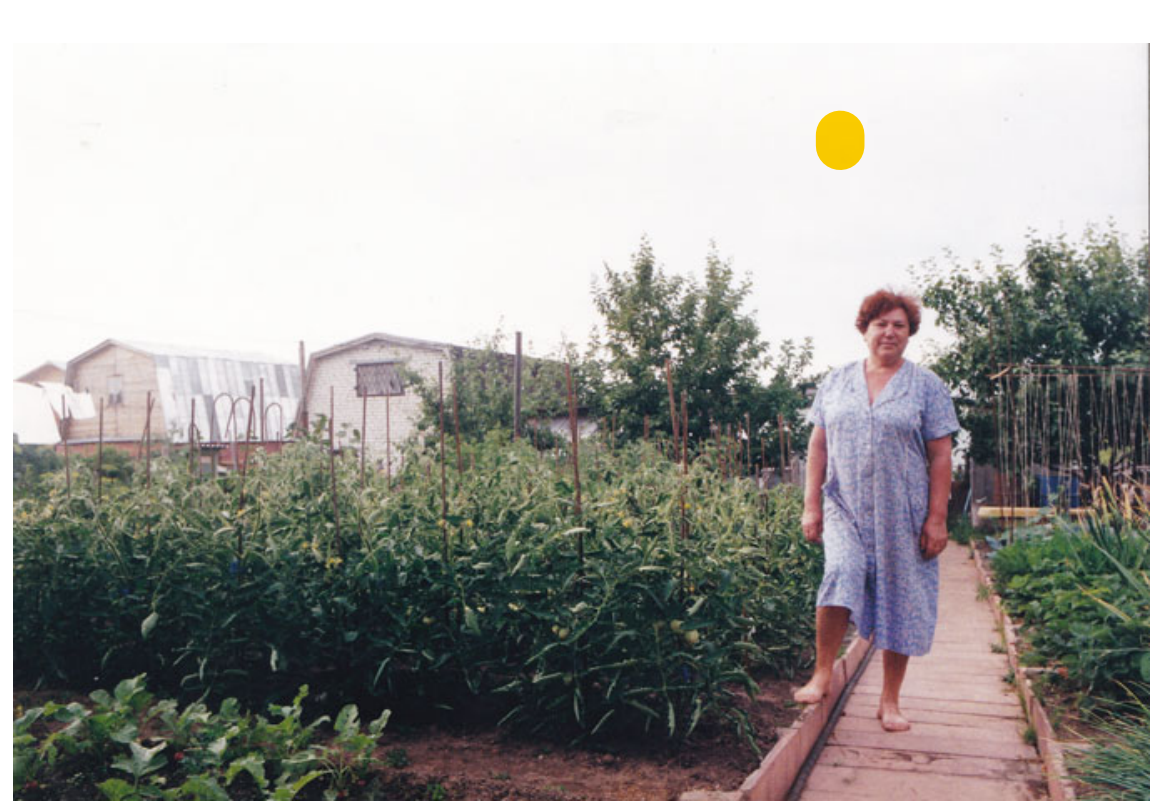

Fig. 5.1 A gardening woman posing in her garden

\section{TRADITIONAL FARMING GARDEN}

Anatolie, a 50-year-old worker, grows tomatoes, cucumbers, zucchinis, beans, cabbages, potatoes, etc., in the so-called Runo garden in adishera (150 plots). In this garden, which he bought in 1980, you can find the whole range of vegetables available in this region of Tatarstan. In front of the house, a few flowers grow for decorative purpose, next to medicinal plants (mint, lemon balm) which the Russians use extensively. He even used to raise pigs and rabbits for a long time, thus making his garden a mini-farming business. The products from his garden and the breeding of his animals provide for all the food basics he and his family need all year long. He grows seeds in the city and plants them in June. The vegetables are then canned to last over the winter period. Anatolie goes to the garden every evening from the beginning of May and until the harvest; he also spends his weekends there.

The datcha, and above all the garden, has an essential economic function in his budget balance. He comes to the datcha "to work, not to rest" except in winter, when he can enjoy the bagna (a traditional sauna-like Russian bath). As a child, he used to observe his parents, who also have a garden, but he prefers saying he learnt the farming techniques on his own. Anatolie only has very little contact with his neighbors; they sometimes exchange knowledge and know-how tips to avoid pests or to grow this or that plant, but there is nothing constant or regular in these conversations which he sees as little compliance talks and basic good manners. 


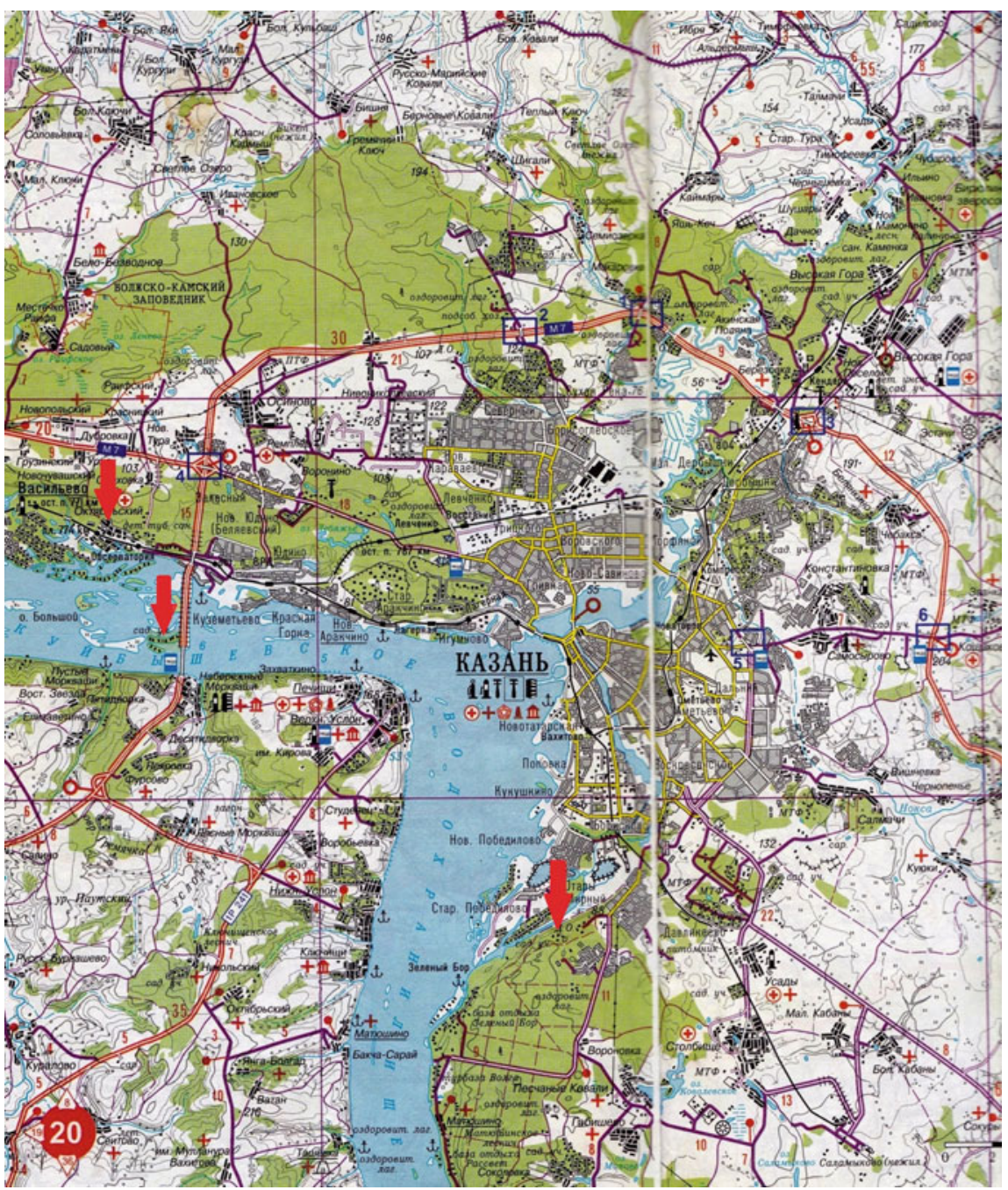

Fig. 5.2 Location of the study-targeted gardens

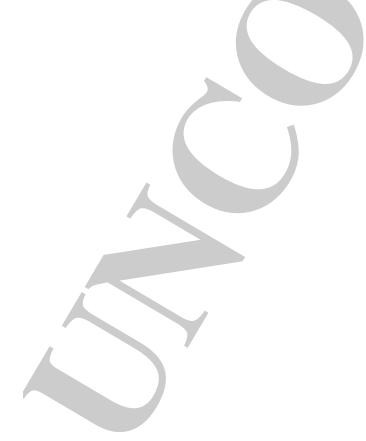




\subsection{The Collective Garden as a Tool for the Analysis of the Changes in the Imaginary Representations of Nature in Contemporary Russia}

The collective garden is an institution that dates back to the first years of the Soviet Union and that enabled urban people to purchase a plot of land-with an average size of $600 \mathrm{~m}^{2}$-in order to start an agricultural activity for domestic purposes. At the very start, each garden depended directly on the institution to which it belonged: This was sometimes a factory, a specialized university, an administration, a hospital, a school, etc. The concept first appeared under Staline and allowed urban citizens to receive minimum wages by their own means of production based on the model of the pieces of land that were distributed to the kolkhoz workers. The collective garden got its real kick start in the two last decades of the Soviet Union (Ortar 2005). It played a major role in the economic survival that came along with the huge transition crisis of 1990 and 1991; however, its vocation cannot merely be confined to the economic sphere, as we are going to see further on. Nowadays, more than twenty-five years after the collapse of the USSR, it remains an important part of the Russians' lives as it provides around ten million urban dwellers, that grew up in the urban-industrial age, with the only possibility of finding a path to stability and of getting back in touch with nature. "Gigantic and soulless cities, endless lines outside the shops, individual freedoms trampled upon, poorly insulated homes and small flats in which entire families cope with promiscuity the best they can, authorized food which we know is contaminated since it comes from Chernobyl... What is the meaning of life in such a world? Against overwhelming odds, the building of small houses and overnight shelters makes its inhabitants forget, for a weekend at least, about their worries," this is how Ronan Hervouet chronicles the genealogy of an original institution which prefigures what we will now call "urban farming," whose early form is the collective garden. To be precise, this "suburban" (1) farming is reported to affect $65-80 \%$ of Russian people nowadays. Although geographically situated in the outskirts of big cities, sometimes up to ten kilometres away, the collective garden is a little bit like a "green town" right beside the metropole: There are main "avenues" from which smaller driveways merge, that contain many plots - sometimes many thousands - on which the famous datcha can be found inevitably, as a new version of the former garden shelter, which the landlords initially built themselves with the help of family members and friends, and which has now become a family home, or at least a secondary home in which families get together at weekends, between May and September. It is not uncommon for mothers to settle there for the holidays. People from every social background are working there side-by-side, there are all kinds of crops, such as vegetables, fruit, flowers, plants, people literally live there, sometimes part of the year, particularly women and children, families and generations gather to participate in a series of activities that are prohibited in the city. 
A WARMLY CONVIVIAL DATCHA (collective garden of Soutchi, 700 plots)

Galina, a 56-year-old retired woman, used to work as a corporate official in a Kazan-based firm. The company in which she worked provided her family with this land in 1990. When they first arrived, they had to build it all up and arrange everything on this sand field that had been created after the building of a bridge. Twenty-five lorries full of land materials were needed to make the ground livable. After that, her husband started building the house and she started setting up the garden. "Men take care of physical work, such as pickaxing for instance. The distribution of domestic work is not systematic, but gardening is rather something for women. Gardening is thought of as a female task." The garden is first and foremost a living place where she can rest and spend time with her family (children, grandchildren) and her friends. Since they have arrived at the time of the great crisis caused by the break-up of the former Soviet Union, there has been an obvious increase in capital gains from the datchas (upstream from the city, on the banks of the Volga, where there is a micro-climate), which have become more and more valuable financially.

As soon as they arrived, they started planted fruit trees and the bushes; the rest of the vegetable crops have been gradually developed (potatoes, cucumbers, tomatoes, etc.).

Galina's garden is much more diverse and richer now that she is retired and that her children are grown up and on their own. She keeps remaining seeds from one year to the next and buys some more from a catalog (she grows more than ten tomato varieties). Before planting, she has a look at the lunar calendar (in specialized magazines and publications). The quantity she produces is enough to avoid buying basic products (tomatoes, cucumbers) in the warm season, and she can even preserve food for the winter months. Galina lives on the plot for the whole "season," from June to October; her husband (who still works) joins her in the evening. Their grandchildren spend most of the school holidays there.

Her garden does not really have an economic function, and the experience of gardening has a rather hedonistic and aesthetic dimension and serves the "love of beautiful things." Therefore, the garden is of course a place to rest, but also a place to experiment new things. The experience gathered year after year allows her to test new ways to grow crops in association (this plant grows faster next to that plant, etc.), to test biological control (this plant moves away the parasites that affect that type of fruit) and even agroecology (ashes or soap-based mixtures as substitutes to artificial fertilizer). Galina learnt gardening with her parents who had an individual house with garden. She has not had the opportunity to pass on her knowledge and 
skills to her children yet, because of their lack of interest in the matter. However, her grandchildren sometimes help her in small tasks. She maintains good relations with her neighbors who share their experience with her, exchange seeds, etc. However, they are not friends but "garden neighbors."

\subsection{A Family-Institution Above All}

Most of the gardens we have visited date back to the 80 s, sometimes even to the 70 s, which means that two and sometimes three generations get together there. The first generation, that had been given the plot in the Soviet period, is slowly dying; however, the challenges concerning the future and the development of those gardens still remain an issue for all three generations. So there is obviously more than one single kind of relation to collective gardens, and there is obviously no "model garden," but rather a typology of agricultural practices, of expectations, of social relations, that are deeply rooted in the historical development of collective gardens. The first "pioneer" generation (ours date back to the eighties, which is quite late on the history scale of the collective garden) has been given gardens "for free" in the framework of collectivism, whereas the following generation had to, and still have to, invest heavily to acquire a plot. In terms of size, the collective gardens differ from one another (ranging from a few dozens to several thousands of plots), just like their quality also differs: the garden of Soutchi, in which we carried out our investigation, near the built-up area of Kazan (1.2 million inhabitants), and at the same time upstream from the city, on the Volga riverside, on a sand island on which there is direct and private access to the river; this has become a "must" for the inhabitants. However, those recreational and aesthetical qualities will not make the happiness of those who wish to make a food production profitable; these people will have to look for a richer land with less frequent flooding, and nevertheless less expensive. Roughly speaking, the historical movement that we wish to describe here ranges from productive gardens to leisure gardens, and all hybrid and intermediate forms. However, other characteristics may arise, as we will see. Therefore, it is quite tricky to fully understand the collective garden institution without considering its historicity, without interviewing different generations of Russians, pioneers, heirs, or buyers of these precious plots; actually, this is prerequisite to draft an exploratory typology of the gardeners in line with their values and expectations (Fig. 5.3).

So these are the generations we will consider throughout this study, even if these categories cannot be held as representative of the all individuals who are supposed to belong to these generations.

- The 60-80-year-old generation: the "pioneers," characterized by their deep rural and farming roots; strongly attached to the food productive use of the gardens

- The 40-60-year-old generation: the "heirs," urban generation whose "farming culture" was acquired in the garden 


\begin{tabular}{|l|lll|}
\hline Layout: T1_Standard & Book ID: 429280_1_En & Book ISBN: 978-3-319-72732-5 \\
Chapter No.: 5 & Date: $28-12-2017$ & Time: $3: 12$ pm & Page: 7/19 \\
\hline
\end{tabular}

5 Russian Collective Gardens: A Story of Institution ...

Fig. 5.3 Datchas and gardens along the Volga

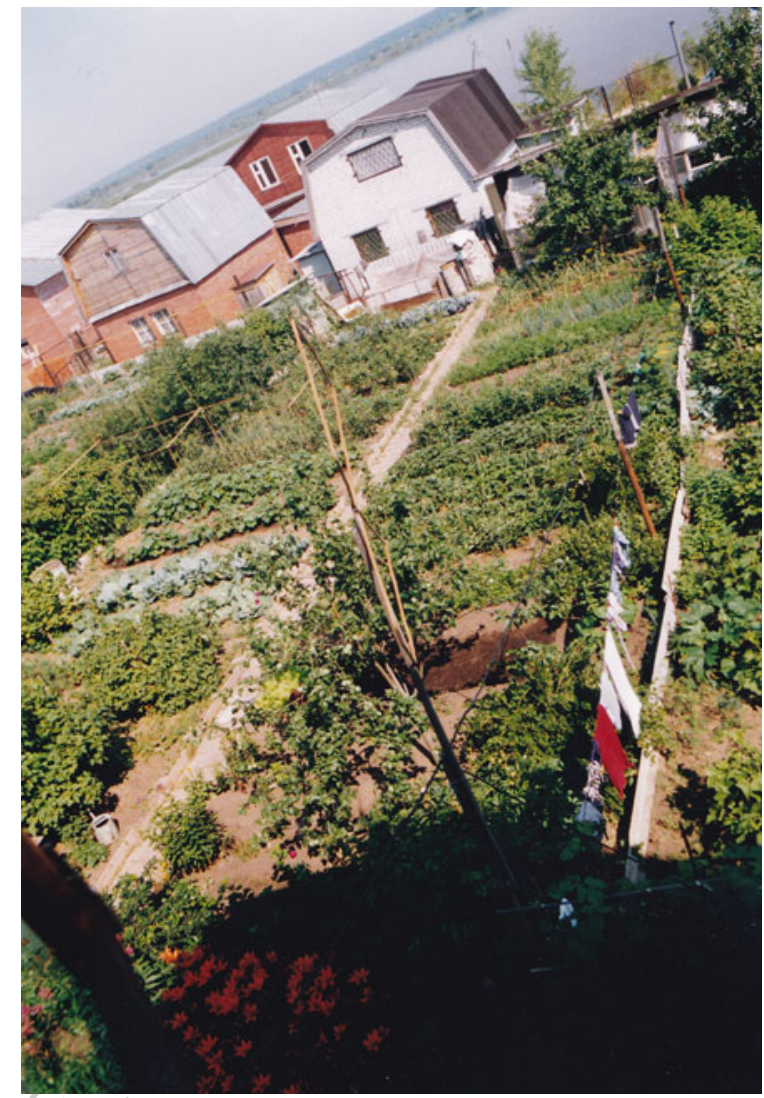

- The 20-40-year-old generation can be of two types: on the one hand, the "new Russians," who tend to develop the occidental-model-based pavilion datcha, this means that it has no vegetable garden; on the other hand, the "young ones" as bearers of new aspirations, and quite reluctant to garden cropping, encouraging new recreational and aesthetic purposes of these gardens.

This means that all age-groups play a role that it at least as important as the part played by social classes, both being historically speaking involved in a process of understanding the attitudes and practices of the gardeners. The perspective of the intergenerational transmission of gardening is a crucial factor: Inheritance, whenever accepted, is seen by most people as a moral duty to carry on the work begun by the parents who cleared the land, fortified and cropped it, planted trees, built a house (the datcha), etc. The weight of this burden to perpetuate ancient family traditions may seem paradoxical when seen through the perspective of current aspirations of the heirs to transform the garden and sometimes even getting rid of it. Hélène took over the datcha and the garden based on the moral duty to respect the legacy of her parents, in order to live "in accordance with traditions" even though 
this has never been her own personal choice. "This garden is like a suitcase without a handle: a heavy load that you cannot leave or even just lay down for a while."

\subsection{The Economic Role: Distinguishing Discourse and Facts}

In the early 1990s, as Russia was deep in economic crisis, the gardens have played a significant and essential role in daily nutrition; however, it is surprising to note that, when asked, most gardeners today tend to deny the economic basis of their work. It has often been said that if we had to take calculations of inputs (buying or hiring of the land, buying of agrochemical products, of fertilizers, eventual buying of plants and seeds, etc.) on the one hand and of outputs on the other hand, the balance would be negative; except for monoculture exploitations, maybe (potatoes for instance). But these are extremely infrequent and usually grown whenever a family finds itself in the situation of inheriting two plots: One of the plots can be used in essentially productive "business" activities; in other words, it is dedicated to selling agricultural products on local markets. It is important to add that the agricultural products delivered by the kolkhoz are cheap and generally of good taste quality (when the extensive cultivation is carried out on good soil conditions).

The gardeners readily admit that the garden products provide varied and healthy food, thus denying the true health hazards arising from pollution of the river in the present case, but at the same time, they all agree to say that it would be more profitable for them to buy vegetables on markets or from the kolkhoz, particularly in the season when the prices are low. But these are only words intended to show the non-utilitarian nature of the gardens and no one really tried to make such a calculation, since it would only be of limited relevance here. We shall note here the existence of the rhetoric of economic disinterest, which means that the real purposes of the gardens are to be found somewhere else: keeping in touch with nature (banned notion in the Soviet industrialist speech), convivialism, recreational and educational activity, etc.

From the economic point of view (in the sense of exchanges), we could state that the gardens are places "for free" following the logic of giving. Here, the use of the adjective "free" refers to the work of nature that human beings have been selling and buying since Neolithic times: All we have to do is plant or seed to harvest the fruit. We then save the seeds, and the cycle goes on. This has indeed become a key issue of careful thoughts given to "nature-provided services," also known as environmental amenities.

This principle of free availability is directly linked to the very logic of living beings reproduction and results in another socio-anthropological principle: It is possible to give out the harvest of nature (through our own work), without losing it, just like we can duplicate computer files or share knowledge. This is how the release for free circulation of crops including seeds, beans, plants (especially in 
spring), but also of empirical knowledge and know-how, occurs between neighbors, family members, or friends. These exchanges/gifts were theorized by Marcel Mauss and gained widespread acceptance (Caillé 1989); they involve a concept of reciprocity — which also fosters biodiversity! — through barter trade practices and all kind of non-monetary transactions such as neighborly goodwill. We had the opportunity to experience this logic of gift every time we visited the gardens; we left back home with arms full of flowers, fruit and vegetables each time and were also often kindly invited to use the bagna.

\section{THE ANTI-CRISIS GARDEN}

In 1980, Tamara and Victor, 48 and 52 years old, were "pioneers" in their garden in Soutchi, which today counts 400 plots, each of $400 \mathrm{~m}^{2}$. They wanted a garden to bring up their children in the middle of nature, while the falling living standards resulting from the perestroika did not allow any vacation or even leisure time in the State's various recreational centers. He uses to work 20 days in a row in the garden and then takes ten days' rest. She spends all her free time there, that is to say from May to September, taking paid vacation here and unpaid time off there. The production of tomatoes, cucumbers, salads, berries, condiments provides partial food self-sufficiency. The economic function of the garden emerged gradually along with the drastic fall in living standards and the declining purchasing power of the working class that started ten years ago. A great part of the production is consumed locally (to the most possible extent), at least during the summer season. Fresh fruits and vegetables are said to taste better; the remainder products are preserved for the winter season. Tamara belongs to the urban generation and has learnt gardening "spontaneously," reading books and magazines, talking her colleagues' advice, and experiencing things. The children and grandchildren have been socialized through garden work; the grandparents take care of their grandson there all summer long. The aesthetic function of the garden is present but secondary. Paradoxically enough, it was much more present at the beginning, when the economic function of the garden was not yet the first concern. The datcha was built up by the husband, with the help of his friends. It was the first step, the garden followed.

Proximity network, automatic solidarity among neighbors. Exchange of products and seeds. Mutual assistance, particularly for hard work and household repairs.

\section{Work, social links}

The issue of work is central in the garden. Work here refers to an activity that involves high-intensity exercise dedicated to change the world - change the land in the present case - to get a product out of it. Gardening a $400-600 \mathrm{~m}^{2}$ plot is an activity that consumes time and attention, sometimes tedious, that could be a 
full-time job for a single person, from spring to autumn. This is what happens in "permaculture" micro-farms that have developed in Europe for the last few years. It should be noted that some people, like retirees, unemployed or part-time workers, take this time. Some others, like employees or freelancers, spend all their free time there, including holidays and weekends. The value of labor occupies a prominent place. The act of gardening is particularly described as a teaching medium for young children: The harvested fruit and the freedom to enjoy consuming it is the product of the work dedicated to nature as a reward for our labor. Older people often use the following proverb to express this connection "You cannot have bread without stalks of wheat!" Just like in the rest of the society, in Russia, the act of gardening is a reality that happens to have a division by sex: Women (sometimes men) take care of the crops. It is fairly rare to see both being simultaneously "masters" of the house. Following a period of empirical observation, we were led to think that the garden is rather a place for women, as it is part of the imaginary continuity of the house. This does not mean that men are inactive, since he has a responsibility - with the support of neighbors and family members - to build and maintain the datcha and its "outbuildings" (toilets, sauna, greenhouses) and to perform the hardest household chores (plowing, ensure manure supply). In some gardens, at the very beginning, it was necessary to import the whole of the arable land; this was a typically masculine task (Fig. 5.4).

"The datcha is not a place to develop friendships," says Hélène, "In the garden, you get to know people but you do not make friends." The idea that the sociability networks among gardeners are different or even distinct from the urban friendship

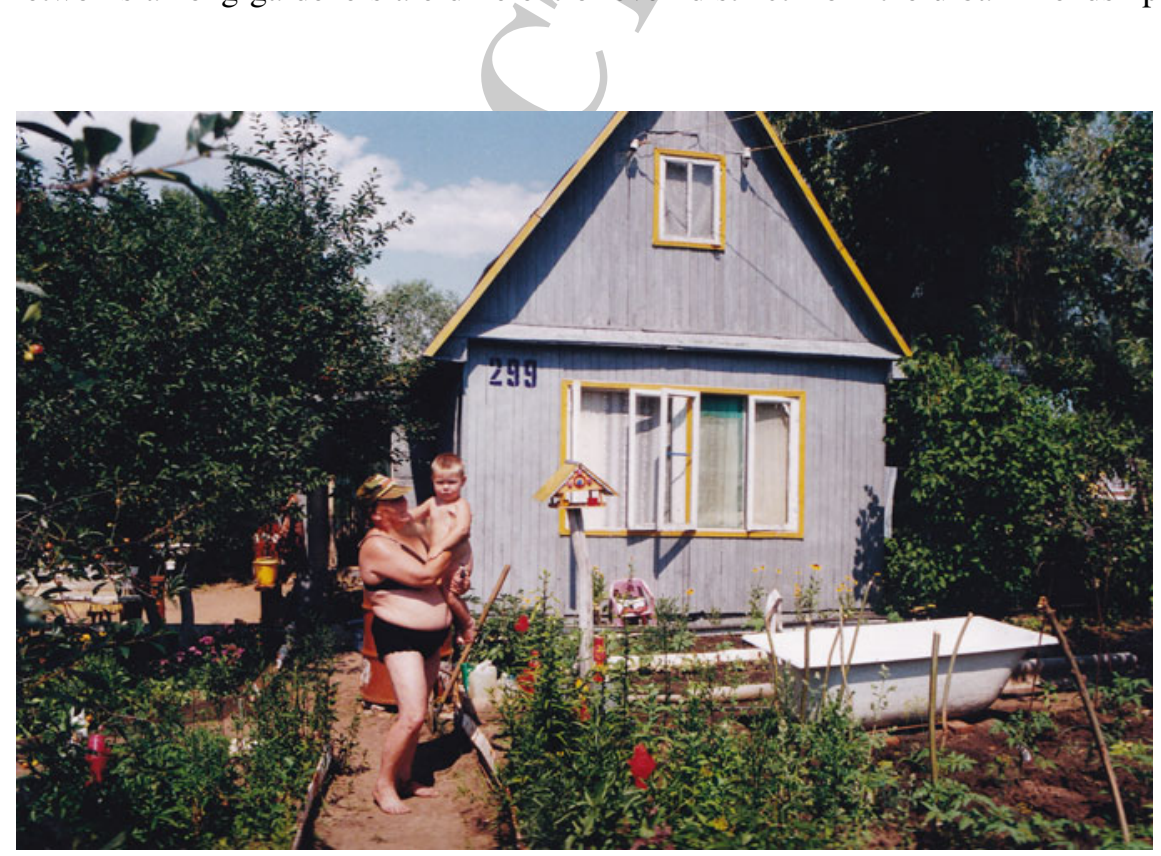

Fig. 5.4 Leisure, family, nature 
networks is not uncommon. Alfia also emphasizes this distinction between the friendly relations she developed in the city and those she developed in the datcha since, she says, "at the datcha, you socialize with your direct neighbors, you do not choose them; in the city, friendship is more selective but the relationships are richer." This is how people regain the ancestral automatic solidarity, particularly in mutual assistance practices, without really considering their neighbors as heart friends. Nevertheless, Alphonso keeps on insisting, like many others, on the existence of convivial moments (the people from his garden often share grilled meals), with a traditional meal to celebrate the end of the season in October. According to him, the relationships are "easier at the datcha than at the Institute, you can talk to people without bothering about social status." Hence, the garden is at the same time a social marker (having a "great" garden is ego-boosting), but also, paradoxically, an eraser of social status, particularly in huge gardens where all social strata from the ex USSR work side-by-side (ranging from the skilled - or not-worker to the director). It goes without saying that the "new Russians" who belong to the financial oligarchy take over other places. However, there is a great deal of socializing practices; all along our stay, our hosts have made real efforts to invite a number of friends to join in and thus find the opportunity to show us the inimitable samovar, topped with its usual boot, old fashion-like, and of course, the traditional Russian barbecue. The meal ritual refers to other various ritualistic procedures from the early customs, just like in western practices: the use of fire, alcoholic beverages, the investment of the outside world, etc.

\section{THE DATCHA-(ecological) COUNTRY HOUSE}

Raphael and Alfia, 42 and 45 years old, respectively, builder in the building industry and biologist, live in Kazan and own a $600 \mathrm{~m}^{2}$ plot on which they grow potatoes, tomatoes, onions, cucumbers, beans, mainly in summer. Raphael built his datcha step-by-step, starting in the nineties, when they bought the garden. In the case of this family, the products grown in the garden have absolutely no economic value. Alfia is the only one taking care of the garden, since Raphael is busy building the house. Raphael works in the private sector and has no time to work in the garden and enjoy it. They could easily "cover the yard with asphalt and place decorative plants," she says. But the interesting thing about the garden is to "watch the crops grow," says Alfia, insisting on the recreational side of the garden for children: One of the main goals of the garden is to "bring the children back to nature" by making it a mini-environmental education center. Alfia has never learnt gardening and her knowledge in biology and her job only help indirectly. She says that she can "feel" what plants need just by looking at them, even though she learnt a few basics from her parents. The datcha may in time become a real holiday house; this is how they bought the plot. For them, the garden is above all a means to forget about their routine work in the city, which, they think, 
is tedious. Social relationships there are limited and "urban," except for a few close friends that they know from the garden. The datcha is modeled on the French country house, where they meet friends that are "external" to the garden. Their three young children even have little summer friends here, that they meet each year.

\subsection{The Garden as a Work of Art Dedicated to Remembrance and as a Vector for the Transmission of the Farming Culture}

During this investigation, we found evidence that could possibly validate the assumption that the garden could be a place of memory and transmission of the farming culture in the Soviet and post-Soviet society. Indeed, many gardeners from the pioneer category admitted that they spent their childhood in the country, in small villages, in connection with the land, the land of the kolkhoz, in connection with animals and with the last Russian farmers, before the Soviet system declared the peasant society as a completely insolvent social class. When asked "where did you learn gardening?", older people frequently answer: "in the village where I grew up," whereas others tell us about their family life in city houses with gardens (there are still a few of those houses in some parts of Kazan, as in many old Russian cities. What we call "memory of the farming culture," is much more than just a series of skills and know-how: It is a collection of concepts and representations of the world, based on particular values and around a collective memory; it is common to all farming cultures that developed on several continents from the year 1000 to the twentieth century. The reproduction of family and social structures, the predominance of particular socializing models (family, friends, neighbors), over secondary socializing models (institutions, trade, State), the development of non-monetary trade (exchange, mutual assistance, gift logic), the direct transmission of skills and know-how, the worries to preserve the environment, the connection to the land, the preservation of collective memory, the development of self-production and home consumption, and finally, the will to maintain personal freedom places are the main characteristics of the memory of farming culture, the ones that industrial and technical modernity simply swept aside, supposedly in the name of Reason (Bitoun and Dupont 2016). The sacrifice of the whole farming population on the altar of productivism and modernity has, indeed, played a particularly violent part in the Soviet experiment that preached for their anthropological change into a working class; to that aim, they were locked into factory farms named kolkhoz, to fit in with the ruling ideology. The repression of peasant movements and the planned destruction of rural societies even turned into a real genocide, in the initial times of the Russian revolution (De Crisnoy 1978). 
This is how one may understand the keen interest of Russians in the gardens, since they serve as a support for the inscriptions of remembrance that has never been fully erased from the farming culture, even though the social, economic, and political class structure of the "peasant society" finally disappeared, as it did in Western Europe (Mendras 1995). Beyond the materiality of things, our investigation led us to discover the extremely rich and complex side of the existing memorial relations, through the testimonies of the three or four generations, the oldest of which still holds the living memory of the Soviet system experiment, and even of the twentieth-century totalitarianism, from the garden institution and the memory of peasant societies. The farming culture, in terms of ethos (a set of values) and praxis (set of historically oriented practices), can be found at different levels of the practices and representations of the gardeners, especially of the "pioneers," who were the first to colonize the land, sometimes with a heavy hand. Its main characteristics are (open-ended list):

- The development of non-monetary trade

- The act of giving excess production to neighbors and friends

- Mutual assistance for tedious tasks and the building of the house

- The limitation in the development of the garden's productive capacities

- Ecological awareness (more or less implicit)

- The establishment of a relationship between working the land and freedom

- Direct transmission of experience

- Inputs self-production and family consumption of the products.

The purposes of the French family or professional use of the garden, whose institutional codes are historically varied, are quite the same. From this point of view, the garden is a symbol of the essential downside to urban and industrial modernity whereby the practices, skills, and social logics that the institutions of modernity have erased in the name of Reason (and economic profitability) can be updated. It is somewhat reminiscent of the reflections undertaken by Jean Baudrillard (1967) on the dialectic that seem to underlie our world of domestic objects: "A whole category of objects seems to evade the rules of a system that we have just analysed (functional): these are baroque, folkloristic, exotic, antique objects. They seem to contradict the requirements of a functional numeracy in response to wishes of another kind: testimony, memory, nostalgia, escape. There is always a temptation really to mean that they represent the survival of a traditional and symbolic order. Although these objects are different, they are all part of modernity, and this is where their double meaning emerges." Wouldn't it be the same logics for collective gardens? It was instituted at the beginning of the twentieth century, essentially for economic reasons, and over time, it has become an institution of remembrance of a relation to nature that got lost in the development of the urban-industrial project; however, it is dedicated to social remembrance. Though it was genuinely a support for memory, at least, this is what the aesthetic and theory of the gardens teaches us (Yates 1975), the garden would now find its place in the Art of Remembrance. Since it provides landscape captures, that is to 
say that the landscape can be understood in its aesthetic and nature-sensitive meaning (Berque), the garden could possibly be seen as a medium between an unovertaken past seeking for modernization - the pre-modern anthropological inheritance — and a present that cannot respond to anthropologically fundamental needs such as rooting, giving "for free," and living a "good life." Our interview with the painter Ildar Zaripov (exhibition at the Tretiakov Museum of Moscow) has brought much like to this subject.

\section{THE GARDEN OF AN ARTIST}

Ildar Zaripov, a 54-year-old Tatar painter, is a well-known figure of Kazan. His $400 \mathrm{~m}^{2}$ garden is located in Kadicheva, on the edge of the city, near the factories, in the south part of Kazan. In 1980, Idar visited a friend in this garden and he saw a "for sale" sign on the datcha. It was love at first sight. Since then, he has grown tomatoes, onions, garlic, various flowers... he has a good standard of living and does not need to earn money from the garden. However, it cannot be denied that his production of vegetables is a direct advantage for his own economy; his wife always cans the excess production to keep food for the winter season. In fact, for Ildar more than for others, his garden has become the continuity of his workshop, or even "a workshop per se" as he says, a kind of vegetal workshop in which the movement of the work of art and the movement of nature both commune: "When I am surrounded by plants, I can rest, ideas cross my mind and I draw them on the canvas, it opens my eyes and nature is right here, I can hear the birds singing; this is the truth about my life."

The transmission of the "art of gardening" shall be done through the work of art more than through social relationships themselves. Hence, some canvas include remnants from the old wheat fields that used to surround the garden, and some others contain representations of garden flowers. According to his own sayings, he learnt gardening through the farming culture that his father left behind him. He had settled in Kazan in the thirties, in an individual house with garden, in which he reproduces the organization of rural life (gardens, trees, farmyard, animals, etc.).

The aesthetic vocation of the garden seems to be a particularly vital concern and does take here a really specific dimension in which the garden stands as a symbol for much more than a "beautiful place," but for the place itself in which beautiful things can be created. Ildar hangs out with neighbors and close friends, with whom he has more "intellectual" than practical relations. In that sense, the word datcha is returning to its original meaning that is a second country home in which the ruling class invited people from good society. 
Ildar's conception of the garden goes deep into the "Russian mind" in its relation to nature. The garden is "intrinsically pure" and helps balance physical and psychological health; this is an image that can also refer to Japanese gardens: "Garden work can also be a way to rest; physical activity brings inspiration and creativity. When I work in the garden, I think."

\subsection{Collective Garden, Landscape, and Transmission}

We now have to consider the anthropological challenges of the contemporary garden properly speaking, by means of an empirical analysis whose limits we are well aware of. To put it in a nutshell: It has a very poor economic value, except in cases of acute crisis. It is definitely a place to socialize, but it is more appropriate to develop "mechanical" relationships with neighbors than real elective friendships. It remains a place for meditation that is deeply rooted within the central community, that is, family, in which people can work/meditate on their own from time to time. Finally, it is only inhabited a few months in a year and remains, most of the time a familial or personal "rustic utopia" of a production obtained from a small "nature monument" which structures expectations. In the garden of Sotchi, Hélène thought that "gardens need to be kept alive because they represent nature, they shall not disappear, men need nature." At this point of our analysis, we think it is helpful to highlight the theoretical contributions of landscape aesthetics and of the art of gardening with the aim to underline the epochal dimension-hypothetically, of course - that structures the connection between gardeners and their terroir/territory (Fig. 5.5).

Let us quickly recall what A. Berque stated: "Societies organize their environment according to their own interpretation of it and, conversely, they interpret it according to the way they organized it." Therefore, the aesthetic connection we are interested in right now finds its roots at the limits between cultural and biological history, at the place in which the gardener finds himself literally "engaged" with his environment. This affordance (the French borrowed the word from the English language), according to Berque, is at the same time of ecologic and cultural nature and enables an attachment to the landscape, a possibility to inhabit this world (from habere: to hold, to take, in Latin). There are only few institutional representations of the garden - in contrast, painting of nature landscapes - except for the individual domestic iconography containing family portraits, since the garden stands out as a separate landscape category per se (just like literature and painting). By opposition to the administered and streamlined universe of the Soviet city - the standardization of which still remains stunning to western people - the garden rises out of the earth to create intimate spaces and build relationships between the self and others through 


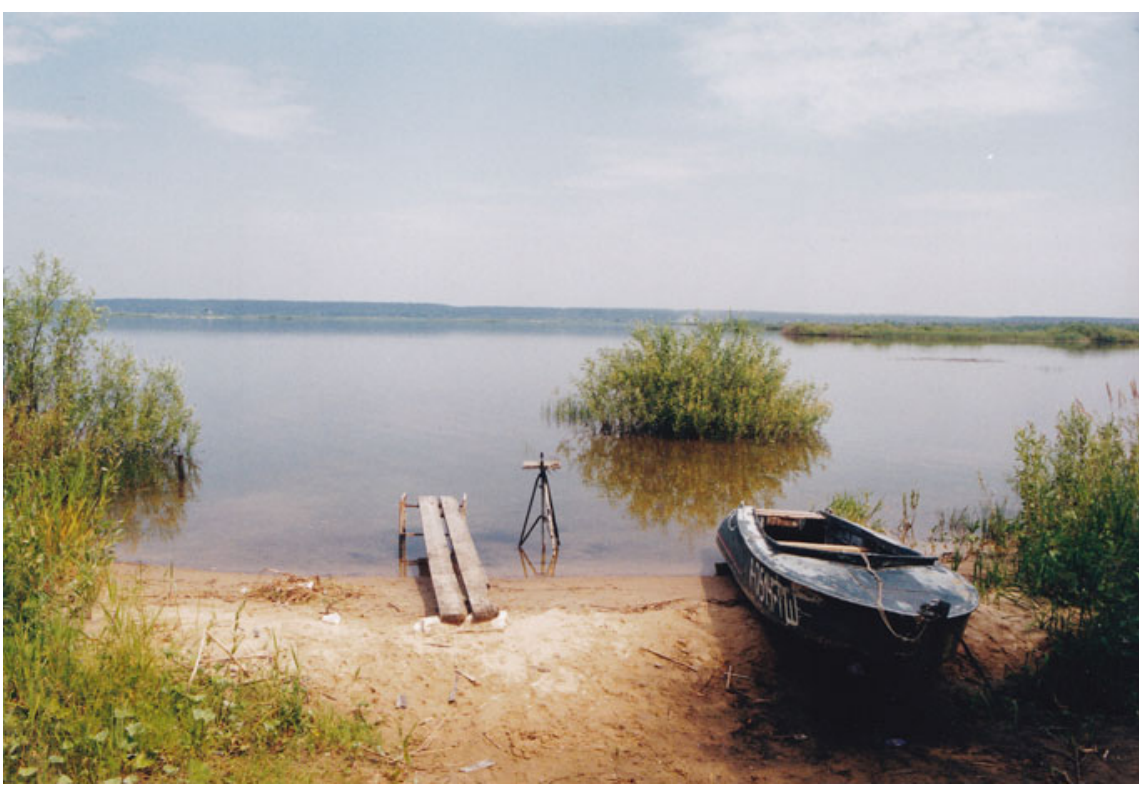

Fig. 5.5 Lakeside landscape «à la Tarkovski» in the garden of Sotchi

the cropping of the land. The point here is that modernity, and most particularly the Soviet scientism that dedicated a boundless passion to the artificial, had distanced itself from nature and founded its anthropology outwardly from it. From the Renaissance onward, landscapes start being set apart from nature, (Luginbühl 1989); this new vision was introduced by the non-peasant strata, since farmers, the country children, are unable to step back and understand these changes (this is the reason why farmers were unable to aestheticize nature). Hence, city dwellers were the first to discover - here to be understood as "invent"-rural landscape by combining three kinds of factors: natural, technic, and symbolic. Gardens, parks, become the natural backdrop for "beautiful landscapes', garden fence were to nature what frames were to paintings: institutionalizing contemplation. Beauty is set aside, suspended; that is the one we were able to admire, within our gardeners' (women for the most part) intimate spaces. But let us not forget that, until the Revolution and probably still afterward, Russian society (except for an aristocratic elite that was closely linked to the Enlightenment) was a deeply rooted rural and farming society. For most people, this change in the aesthetic approach of nature emerged with a move toward industrialization in the twentieth century, in conjunction with the institution of collective gardens. This sanctification of nature is consubstantial with the end of family farming, but this will receive no further debate. The hurtling of Soviet modernity (Moore 1966) involved a three dimensional, identical, and standardized urban space, which resulted in the neutralization of real sites. A famous Soviet comedy sheds light on this reality through the story of 


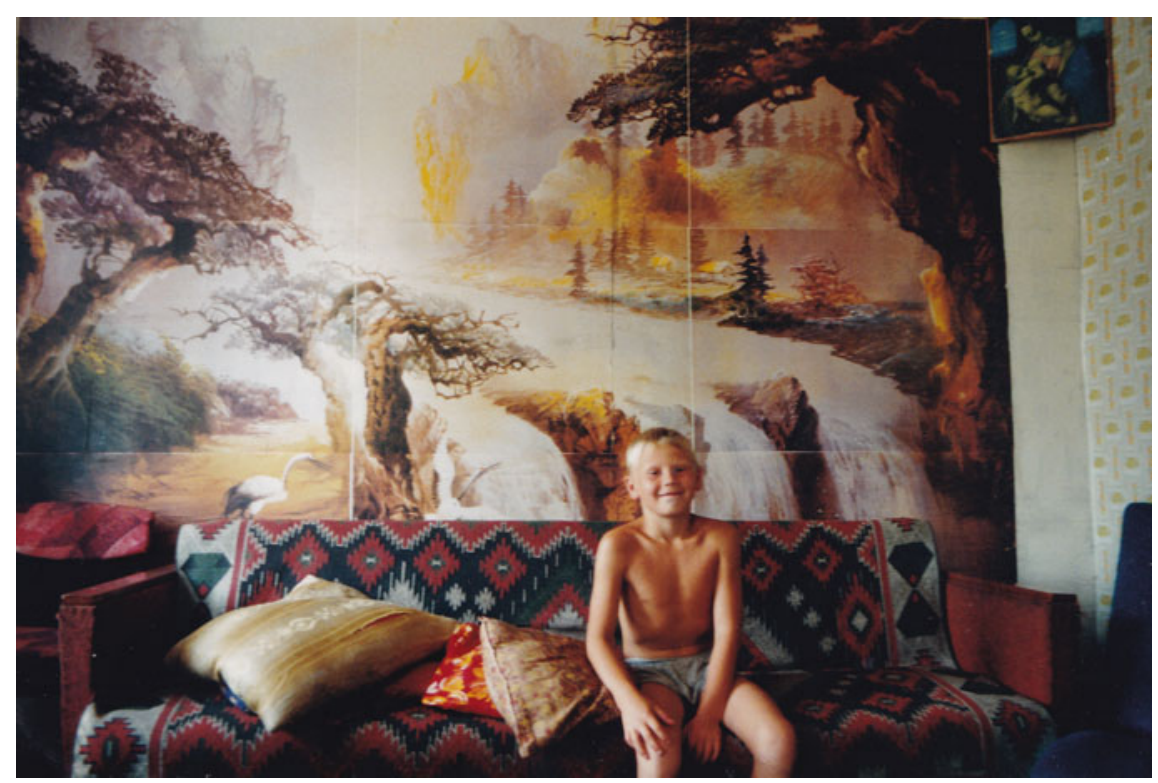

Fig. 5.6 The exploration of the "beautiful nature" in the datcha

a man driving back home, who takes the wrong street in the wrong city and comes into the wrong apartment for it looks exactly the same as his. The image of the garden stands in opposition to this space on which no one can have a proper grip; it is a complex place that seems to link elements that had been set apart for modernity's stake: on the one hand, the local and global, the universal and particular (in the ecological paradigm); on the other hand, the physical and logical, the material and spiritual (in the phenomenological paradigm) (Fig. 5.6).

\section{THE POST-SOVIET URBAN DATCHA}

Guselle is 29 years old and works as a shopkeeper in Kazan; she took over a piece of land from his brother-in-law in 1998. It must be seen as an opportunity rather than as an active decision. This land was chosen for its location, near the city and on the banks of the Volga. It contains a datcha without a garden and thus without any vegetable crops and is surrounded by lawn arranged for children games. Her house, as well as that of her brother-in-law, has been built up on the site, following the European model: They have a prefabricated house; his husband assembled the panels and bounded it all with bricks; the second house has been built by professionals. However, her husband built the bagna, a traditional Russian "sauna." Here, the datcha is exclusively devoted to rest: "We don't think that we need a garden, we come here once a week to rest." Guselle explains this choice by telling us that a garden entails considerable expenses and that she and her husband would 
rather spend that money on children's games and on all comfort and amenities for the datcha. Moreover, her occupation only leaves very little time for leisure activities. Guselle also admits her lack of interest in gardening; at the most, she is thinking of planting raspberries and blackcurrant berries for the children. The household does not need a garden to have best quality products since Guselle's mother owns a large plot $\left(600 \mathrm{~m}^{2}\right)$ and provides her family with fruit and vegetable during the nice season and canned products for the winter season. Although she rules out working in the garden, Guselle enjoys fishing on the Volga with her husband; they own a small motorboat which they use for this purpose. Guselle and her husband keep up with the neighbors; her neighbor brings her fruit and vegetables whenever she has too much of it, even though they do not belong to the same social class. The discussions are friendly: meal sharing, mutual invitations to birthday parties, games (chess), etc.

\subsection{Conclusion}

The recent evolution of the datcha through an approach based more and more on aesthetics and less and less on production could be seen as an attempt to move beyond modernity (which is here the genuine economic function of the collective garden) has started. Of course, this is not a matter of reverting to the original empathy of the subject (the farmer) toward the object (nature) but of going beyond this distinction. Following the model western suburban gardens, each plot tends to become a kind of small eco-museum, an eco-emblematic temple of our time, a small nature monument that does not tell the "great victorious national Tales" anymore but rather small particular stories of universal value. Augustin Berque tells us that the post-modern paradox has enabled a re-sanctification of nature "in proportion to the profane knowledge brought by science." This dynamics can be understood from the metamorphosis and transmissions of the gardens generation after generation, and from the restoration that enables their survival, even if their function has changed. If reality seems to be complex, it is because all the above-mentioned dimensions can coexist within a single garden, just like the datchas are home to all generations.

The meaning of the garden thus finds itself at a crossroads between the wish of the elderly to perpetuate solidarity in the family, with the garden's production being strictly divided up between family members (particularly toward progeny) but also dispatched among neighbors and friends in order to structure a sociability network. However, the new aspiration of the post-Soviet generation that is now old enough to procreate introduces an intergenerational break (abandonment of the agricultural activity or even of the garden) which (dialectically) calls for greater family 
structures. The transformation of the datchas finally appears to be a powerful anthropological factor that reveals the changes of Russian society (and, on a broader level, of post-Soviet societies like Ukraine and Belarus), caught between, on the one hand, the continuation of the modern industrial dream involving a tear-off from the land and, on the other hand, the dream of going back to nature, thus maintaining a solid bond with tradition, family, and the land. New forms of sociability and of land use forms might arise from this preservation of species, knowledge, know-how and memories that may all serve as a basis for transition societies.

\section{References}

Alexiévitch S (1998) La Supplication. Lattès, Paris

Bitoun P, Dupont Y (2016) Le sacrifice des paysans, L'échappée (ed.)

Caillé A (1989) Critic of utiliarianism, La Découverte

De Crisnoy C (1978) Lénine face aux moujiks. Seuil, Paris

Gessat-Anstett E (2001) Du collectif au communautaire. À propos des réseaux familiaux dans la Russie post-soviétique. L'Homme 157:115-136

Hervouet R (2009) Datcha blues. Existences ordinaires et dictature en Biélorussie, Belin, Paris Luginbühl Y (1989) Paysages, représentations des paysages du siècle de Lumières à nos jours. La Manufacture, Lyon

Mendras H (1967, reed) The end of the peasants, Actes Sud, coll. «Babel», Arles

Mendras H (1995, reed) Les sociétés paysannes, Armand Colin, coll. «U»; Paris

Moore B (1966) Social origins of dictatorship and democracy: lord and peasant in the making of the modern world

Ortar N (2005) Les multiples usages de la datcha des jardins collectifs. Anthropologie et sociétés 29(2):169-185

Yates F (1975) The art of memory. Gallimard, Paris

\section{Author Biography}

Frédérick Lemarchand sociologist, is a Full Professor at the University of Caen. Director of the Risk Netwok (Institut for Humanities), he began his research on various environmental topics. In 1995, he started to analyze the social consequences of the Chernobyl disaster, for 10 years (and included the nuclear Fukushima disaster, in 2011). He pursues a personal reflection about transhumanism, relationships between humanity and techniques, environmental transitions, and democracy. He is a member of numerous scientific journals (as Vertigo, CA), director of many Ph.D. on this topics, and member of the scientific council of CRIIGEN (Committee for Independent Research and Information on Genetic Engineering). 


\section{Author Query Form}

\section{Book ID : 429280_1_En}

Chapter No: $\mathbf{5}$

\section{를 Springer}

the language of science

\section{Please ensure you fill out your response to the queries raised below and return this form along with your corrections.}

\section{Dear Author,}

During the process of typesetting your chapter, the following queries have arisen. Please check your typeset proof carefully against the queries listed below and mark the necessary changes either directly on the proof/online grid or in the 'Author's response' area provided below

\begin{tabular}{|c|c|c|}
\hline Query Refs. & Details Required & or's Response \\
\hline AQ1 & As chapter-wise Keywords are mandatory, please provide the keywords. & \\
\hline AQ2 & $\begin{array}{l}\text { Please check and confirm if the inserted citations of 'Figs. } 5.1-5.6 \text { ' are } \\
\text { correct. If not, please suggest an alternate citations. Please note that figures } \\
\text { should be cited sequentially in the text. }\end{array}$ & \\
\hline AQ3 & $\begin{array}{l}\text { Please check the spelling of the terms 'Kadisheva', 'Kadicheva', and 'Risk } \\
\text { Netwok' in the chapter. }\end{array}$ & \\
\hline AQ4 & $\begin{array}{l}\text { Please check the clarity of the phrase '(1) farming is reported' in the sentence } \\
\text { 'To be precise... of Russian people nowadays'. }\end{array}$ & \\
\hline AQ5 & $\begin{array}{l}\text { Please suggest whether the sentence 'People from every social...in the city' } \\
\text { conveys the intended meaning. }\end{array}$ & \\
\hline AQ6 & $\begin{array}{l}\text { Please suggest whether the usage of the phrase 'started planted fruit trees' is } \\
\text { OK in the sentence 'As soon as they...'. }\end{array}$ & \\
\hline AQ7 & Please suggest whether the heading 'A Family-Institution Above All' is OK. & \\
\hline AQ8 & $\begin{array}{l}\text { Please provide the appropriate years for ' } 80 \text { s', ' } 70 \text { s', 'eighties', 'thirties', and } \\
\text { 'nineties'. }\end{array}$ & \\
\hline AQ9 & $\begin{array}{l}\text { Both 'Soutchi' and 'Sotchi' are used inconsistently in the chapter. Please } \\
\text { suggest which one is to be followed throughout. }\end{array}$ & \\
\hline AQ10 & $\begin{array}{l}\text { Please check the clarity of the sentence 'This means that...ppractices of the } \\
\text { gardeners'. }\end{array}$ & \\
\hline AQ11 & $\begin{array}{l}\text { Please check the clarity of the phrase 'except for monoculture exploitations, } \\
\text { maybe' in the sentence 'It has often been...' }\end{array}$ & \\
\hline AQ12 & $\begin{array}{l}\text { Please suggest whether the sentence 'However, there is a...traditional } \\
\text { Russian barbecue' conveys the intended meaning. }\end{array}$ & \\
\hline AQ13 & $\begin{array}{l}\text { Please check and confirm the edits made in the sentence 'The reproduction } \\
\text { of family...name of Reason'. }\end{array}$ & \\
\hline $\mathrm{AQ}$ & $\begin{array}{l}\text { Please suggest whether the phrase 'are quite the same' can be changed to 'is } \\
\text { quite the same' in the sentence 'The purposes of the... quite the same'. }\end{array}$ & \\
\hline & $\begin{array}{l}\text { Reference 'Jean Baudrillard (1967)' is cited in the text but not provided in } \\
\text { the reference list. Please provide the respective reference in the list or delete } \\
\text { this citation. }\end{array}$ & \\
\hline & $\begin{array}{l}\text { Please check the clarity of the sentence 'Gardens, parks...institutionalizing } \\
\text { contemplation'. }\end{array}$ & \\
\hline
\end{tabular}


Please check and confirm the edit made in the sentence 'This sanctification of nature...no further debate'.

The citations 'Moore (1969), Bitoun and Dupont (2006)' has been changed to 'Moore (1966), Bitoun and Dupont (2016)' to match the author name/date in the reference list. Please check here and in subsequent occurrences, and correct if necessary.

AQ19 Please confirm the section headings are correctly identified.

Please check the clarity of the sentence 'New forms of sociability...for transition societies'.

References 'Alexiévitch (1998), Mendras (1967)' are given in the list but not cited in the text. Please cite in text or delete from the list. 


\section{Please correct and return this set}

Please use the proof correction marks shown below for all alterations and corrections. If you wish to return your proof by fax you should ensure that all amendments are written clearly in dark ink and are made well within the page margins.

\begin{tabular}{|c|c|c|}
\hline Instruction to printer & Textual mark & Marginal mark \\
\hline Leave unchanged & ... under matter to remain & ( $)$ \\
\hline $\begin{array}{l}\text { Insert in text the matter } \\
\text { indicated in the margin }\end{array}$ & $\Lambda$ & $\begin{array}{l}\text { New matter followed by } \\
h \text { or } h \otimes\end{array}$ \\
\hline Delete & $\begin{array}{l}\text { I through single character, rule or underline } \\
\text { or }\end{array}$ & $\sigma$ or $\sigma / 2$ \\
\hline $\begin{array}{l}\text { Substitute character or } \\
\text { substitute part of one or } \\
\text { more word(s) }\end{array}$ & I through letter or & $\begin{array}{l}\text { new character / or } \\
\text { new characters / }\end{array}$ \\
\hline Change to italics & — under matter to be changed & $\leftarrow$ \\
\hline Change to capitals & $\equiv$ under matter to be changed & $\equiv$ \\
\hline Change to small capitals & $=$ under matter to be changed & $=$ \\
\hline Change to bold type & $\sim$ under matter to be changed & $\sim$ \\
\hline Change to bold italic & $\bar{\sim}$ under matter to be changed & 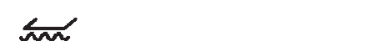 \\
\hline Change to lower case & Encircle matter to be changed & $\Rightarrow$ \\
\hline Change italic to upright type & (As above) & \\
\hline Change bold to non-bold type & (As above) & nor \\
\hline Insert 'superior' character & $\begin{array}{l}/ \text { through character or } \\
\alpha \text { where required }\end{array}$ & $\begin{array}{l}y^{\prime} \text { or } y \\
\text { under character } \\
\text { e.g. } y^{2} \text { or } y^{2}\end{array}$ \\
\hline Insert 'inferior' character & (As above) & $\begin{array}{l}\lambda \\
\text { over character } \\
\text { e.g. } \hat{\Sigma}\end{array}$ \\
\hline Insert full stop & (As above) & $\odot$ \\
\hline Insert comma & (As above) & , \\
\hline Insert single quotation marks & (As above) & $\begin{array}{l}\dot{y} \text { or } \dot{x} \text { and/or } \\
\dot{y} \text { or } \dot{y}\end{array}$ \\
\hline Insert double quotation marks & (As above) & $\begin{array}{l}\ddot{y} \text { or } \ddot{x} \text { and/or } \\
\ddot{y} \text { or } \ddot{x}\end{array}$ \\
\hline Insert hyphen & (As above) & 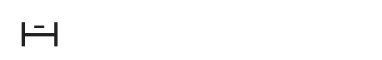 \\
\hline Start new paragraph & 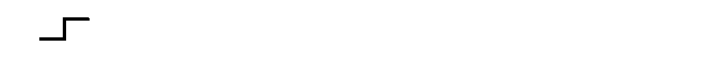 & 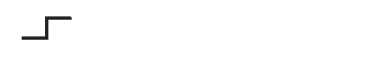 \\
\hline No new paragraph & 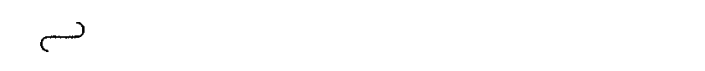 & 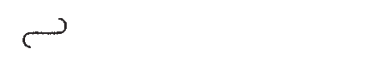 \\
\hline Transpose & $\sqcup$ & $\sqcup$ \\
\hline Close up & linking $\bigcirc$ characters & \\
\hline $\begin{array}{l}\text { Insert or substitute space } \\
\text { between characters or words }\end{array}$ & $\begin{array}{l}\text { I through character or } \\
\Lambda \text { where required }\end{array}$ & \\
\hline $\begin{array}{l}\text { Reduce space between } \\
\text { characters or words }\end{array}$ & $\begin{array}{l}\text { between characters or } \\
\text { words affected }\end{array}$ & $\uparrow$ \\
\hline
\end{tabular}

